\title{
ALOKASI BELANJA MODAL UNTUK PELAYANAN PUBLIK: PRAKTIK DI PEMERINTAH DAERAH
}

\author{
Lufki Laila Nurhidayati \\ Universitas Muhammadiyah Yogyakarta \\ Rizal Yaya \\ Universitas Muhammadiyah Yogyakarta \\ e-mail: r.yaya@umy.ac.id atau rizalyaya@gmail.com
}

\begin{abstract}
The purpose of this research is to see how local governments allocate capital expenditure for public services and to identify factors that influence the allocation. 142 local governments were used as sample, consising of 23 cities and 119 regencies. Budget realisation reports from 2010 to 2012 were used for analysis. The descriptive statistics shows that the proportion of capital expenditure to total expenditure for city governments are relatively homogenous between 10 to $30 \%$ but varied for regency governments. The multiple linear regression analysis shows that budget effectiveness rate and special purpose grant have positive influence on the proportion of capital expenditure.
\end{abstract}

Keywords: local government, proportion of capital expenditure, budget effectiveness rate, special purpose grant

\begin{abstract}
Abstrak
Penelitian ini bertujuan untuk melihat bagaimana pemerintah daerah mengalokasikan belanja modal untuk pelayanan publik dan untuk mengidentifikasi faktor-faktor yang mempengaruhi proporsi alokasinya. Terdapat 142 pemerintah daerah yang digunakan sebagai sampel yang terdiri dari 23 kota dan 119 kabupaten. Analisis penelitian ini didasarkan pada laporan realisasi anggaran dari tahun 2010 sampai dengan 2012. Berdasarkan statistik deskriptif terlihat proporsi belanja modal terhadap total belanja pemerintah kota relatif sama antara 10 hingga $30 \%$, tetapi belanja pemerintah kabupaten lebih bervariasi. Analisis regresi linier berganda menunjukkan bahwa efektifitas anggaran dan Dana Alokasi Khusus berpengaruh positif signifikan terhadap proporsi belanja modal.
\end{abstract}

Kata kunci: pemerintah daerah, proporsi belanja modal, tingkat efektifitas anggaran, dana alokasi khusus

\section{PENDAHULUAN}

Berdasarkan Undang-undang No. 32 Tahun 2004 tentang Pemerintahan Daerah, penyelenggaraan pemerintahan daerah dilakukan berdasarkan asas otonomi dan tugas pembantuan. Ini berimplikasi pada daerah-daerah untuk memiliki hak, kewenangan dan kewajiban otonom untuk mengatur dan mengurus rumah tangganya sendiri dalam urusan pemerintahan dan kepentingan masyarakat setempat sesuai dengan peraturan perundangundangan. Selain itu, Pemerintah daerah
(Pemda) juga memiliki kewenangan dalam mengontrol terlaksananya anggaran daerah (APBD) di bawah pengawasan pemerintah pusat.

Dalam alokasi anggaran, pemerintah memiliki dua alternatif penggunaan yaitu: Belanja Langsung yang langsung berkaitan dengan kegiatan pemerintah yang diperuntukkan bagi masyarakat dalam berbagai program layanan barang, jasa dan fasilitas, dan; Belanja Tidak Langsung yang bersifat operasional rutin yang tidak langsung berkaitan dengan 
kegiatan untuk masyarakat. Semakin besar porsi alokasi anggaran Belanja Tidak Langsung, semakin kecil porsi alokasi anggaran yang dirasakan langsung oleh masyarakat. Pemerintah yang bersifat pragmatis jangka pendek sangat mungkin mengorbankan alokasi anggaran Belanja Langsung untuk masyarakat guna memperbesar alokasi yang bersifat tidak langsung seperti untuk pemberian berbagai macam tunjangan para pegawai dan pejabat Pemda.

Salah satu komponen Belanja Langsung adalah Belanja Modal yang disamping langsung dirasakan oleh masyarakat juga memiliki manfaat jangka panjang. Belanja modal untuk pelayanan publik adalah belanja yang digunakan untuk membiayai kegiatan investasi (menambah aset) yang ditujukan untuk peningkatan sarana dan prasarana publik yang hasilnya dapat digunakan langsung oleh masyarakat. Beberapa penelitian berkaitan Anggaran Pendapatan dan Belanja Daerah (APBD) telah mengkaji tentang faktor-faktor yang mempengaruhi belanja modal Pemda. Akan tetapi jika dilihat dari aspek political will Pemda, isu strategis belanja modal tidaklah pada peningkatan nilai nominal belanja modal melainkan pada peningkatan proporsi belanja modal. Pemda yang punya komitmen kuat untuk keberhasilan pembangunan yang bersifat jangka panjang, tidak saja meningkatkan nominal belanja modal, melainkan juga meningkatkan porsi belanja modal terhadap keseluruhan belanja daerah.

Penelitian ini dilakukan untuk melihat pola alokasi belanja modal Pemda. Penelitian ini dipandang penting mengingat upaya-upaya yang dilakukan Pemda untuk meningkatkan penerimaan daerah selama ini kurang diikuti dengan upaya untuk meningkatkan pelayanan publik (Halim dan Abdullah 2003). Terdapat dua pertanyaan penelitian yang hendak dijawab dalam penelitian ini yaitu (1) bagaimana alokasi belanja modal Pemda jika dibandingkan dengan total pengeluaran pemerintah, dan; (2) apa saja faktor yang berpengaruh terhadap proporsi belanja modal Pemda.

\section{TINJAUAN PUSTAKA DAN PERUMUSAN HIPOTESIS}

Menurut Anthony dan Govindarajan (2005), teori agensi adalah hubungan atau kontrak antara principal dan agent. Teori agensi menggambarkan bahwa tiap-tiap individu semata-mata termotivasi oleh kepentingan dirinya sendiri sehingga menimbulkan konflik kepentingan antara principal dan agent. Pincipal adalah pihak yang mempunyai wewenang untuk melakukan tindakantindakan, termasuk pendelegasian otoritas atas kebijakan-kebijakan kepada agen. Adapun agent, adalah pihak yang menerima otoritas dari prinsipal.

Dalam penelitian Eisenhardt (1989) dijelaskan bahwa teori agensi menggunakan tiga sifat manusia yaitu: (1) Manusia pada umumnya mementingkan diri sendiri (self interesì; Manusia memiliki daya pikir terbatas mengenai persepsi masa mendatang (bounded rationality), dan; (3) Manusia selalu menghindari resiko (risk averse). Ini menunjukkan bahwasannya ada hal mendasar yang kemudian menjadi sebuah masalah dalam suatu sistem, khususnya di sistem pemerintahan yaitu benturan kepentingan antara eksekutif (agen) dan legislatif (prinsipal) yakni salah satunya mementingkan pihak masing-masing demi kesejahteraan masingmasing pihak. Masalah yang biasanya terjadi adalah karena asimetris informasi terkait penganggaran dan pelaksanaan anggaran. Dalam hal ini eksekutif lebih mengetahui informasi daripada legislatif disebabkan eksekutif mengetahui kondisi secara langsung dan memahami birokrasi-administrasi serta perundang-undangan yang menjadi dasar segala aspek pemerintahan. Oleh sebab itu, eksekutif dapat menganggarkan belanja lebih besar dan untuk pendapatannya lebih kecil. Hal ini dilakukan untuk memberi posisi aman pada eksekutif, dimana ketika ternyata dalam realisasi belanja lebih sedikit daripada yang dianggarkan, maka kinerja eksekutif akan terlihat baik. Begitu pula sebaliknya jika dalam realisasi pendapatan dapat memenuhi target anggaran bahkan bisa lebih, maka 
kinerja eksekutif juga akan terlihat baik (Halim 2002).

Belanja daerah merupakan semua pengeluaran dari rekening kas umum daerah yang dapat mengakibatkan berkurangnya nilai ekuitas dana sebagai kewajiban daerah dalam satu tahun anggaran serta tidak akan diperoleh pembayarannya kembali oleh daerah. Belanja juga dirinci menurut urusan Pemda, organisasi, program, kegiatan, kelompok, jenis, obyek dan rincian obyek belanja. Secara ringkas struktur belanja daerah tersebut terdiri atas Belanja Langsung dan Belanja Tidak Langsung. Belanja Tidak Langsung meliputi Belanja Pegawai Harian, Belanja Bunga, Belanja Subsidi, Belanja Hibah, Belanja Bantuan Sosial, Belanja Bagi Hasil dan Bantuan Keuangan dan Belanja Tak Terduga. Adapun Belanja Langsung meliputi Belanja pegawai, Belanja Barang dan Jasa, dan Belanja Modal.

Proporsi belanja modal adalah persentase belanja modal dibandingkan terhadap total belanja (Belanja Langsung dan Belanja Tidak Langsung). Proporsi ini bisa dikatakan sebagai indikator political will (keseriusan) pemerintah kabupaten/kota dalam menentukan proporsi belanja modal yang diperuntukkan untuk pelayanan publik. Anggaran suatu daerah sangat mungkin memiliki angka nominal yang tinggi dibanding daerah lain, namun jika dibandingkan dengan total belanja, proporsinya sangat mungkin lebih rendah. Kendati secara nominal tinggi, dalam konteks ini, political will (keseriusan) pemerintah dalam hal pelayanan terhadap publik perlu dipertanyakan.

Penelitian penelitian terdahulu telah dilakukan untuk mengkaji faktor-faktor yang mempengaruhi belanja modal. Beberapa aspek telah diidentifikasi sebagai faktor yang mempengaruhi belanja modal suatu daerah seperti kemandirian daerah, efisiensi daerah, efektifitas anggaran, Sisa lebih perhitungan anggaran, Dana Alokasi Khusus dan Dana Alokasi Umum. Dalam penelitian ini semua aspek tersebut digunakan kembali untuk menguji pengaruhnya terhadap proporsi belanja modal.
Kemandirian keuangan daerah menunjukkan bahwa Pemda mampu untuk membiayai sendiri kegiatan pemerintahan, pembangunan dan pelayanan kepada masyarakat yang telah membayar pajak dan retribusi sebagai sumber pendapatan yang diperlukan daerah (Halim 2002). Indikator kemandirian keuangan suatu daerah adalah rasio Pendapatan Asli Daerah (PAD) terhadap total pendapatan. PAD merupakan salah satu tolok ukur dalam pelaksanaan otonomi daerah. Pada umumnya daerah dikatakan siap melaksanakan otonomi daerah bila dapat memberikan sumbangan yang besar pada APBD (Siregar 2004). Hal ini terbukti bahwa daerah yang besar PAD-nya dapat dikatakan daerah yang mandiri. Berdasarkan pemaparan di atas, maka dapat diturunkan hipotesis sebagai berikut:

$\mathrm{H}_{1}$ : Kemandirian daerah berpengaruh positif terhadap belanja modal yang diperuntukkan bagi pelayanan publik

Pendapatan Asli Daerah (PAD) merupakan pendapatan daerah yang berasal dari sumber-sumber penerimaan murni daerah. PAD dipergunakan untuk pembiayaan penyelenggaraan otonomi daerah. Untuk itu PAD harus diupayakan agar selalu meningkat seiring dengan peningkatan pelayanan kepada masyarakat. PAD merupakan salah satu tolak ukur dalam pelaksanaan otonomi daerah. Pada umumnya daerah dikatakan siap melaksanakan otonomi daerah bila padanya memberikan sumbangan yang besar pada APBD (Siregar 2004). Suatu daerah dapat dikatakan efektif apabila jumlah realisasi pendapatan lebih tinggi daripada target yang ditetapkan.

Penelitian yang dilakukan Ardhini dan Handayani (2011) menyebutkan bahwa rasio efektivitas keuangan daerah berpengaruh positif terhadap belanja modal untuk pelayanan publik. Berdasarkan pemaparan penelitian sebelumnya, maka hipotesis pada penelitian ini adalah sebagai berikut:

$\mathrm{H}_{2}$ : Efektivitas keuangan daerah berpengaruh positif terhadap belanja modal yang diperuntukkan untuk pelayanan publik 
Aspek lain yang dianggap berpengaruh terhadap belanja modal adalah efisiensi anggaran. Indikator rasio efisiensi anggaran adalah total pengeluaran daerah dibandingkan dengan total pendapatan daerah. Suatu daerah dikatakan efisien jika pengeluaran daerah lebih kecil dari total pendapatannya. Penelitian Ardhini dan Handayani (2011) menyatakan bahwa rasio efisiensi keuangan daerah berpengaruh negatif namun signifikan terhadap alokasi belanja modal untuk pelayanan publik. Akan tetapi Vegasari (2011) menyebutkan bahwa rasio keefisienan keuangan Pemda tahun lalu berpengaruh positif signifikan terhadap belanja modal tahun berikutnya. Semakin besar political will untuk proporsi belanja modal yang besar menuntut Pemda untuk menggunakan sumber daya yang dimilikinya semaksimal mungkin untuk belanja modal. Komitmen ini sangat mungkin mengabaikan penghematan yang dimungkinkan dari Belanja modal membutuhkan dana yang besar. Sebaliknya keinginan Pemda untuk adanya saving dari anggaran sangat mungkin mengakibatkan berkurangnya alokasi anggaran untuk belanja modal. Maka dalam penelitian ini dapat diturunkan hipotesis sebagai berikut:

$\mathrm{H}_{3}$ : Efisiensi keuangan daerah berpengaruh negatif terhadap belanja modal yang diperuntukkan untuk pelayanan publik

Disamping kemandirian daerah, efektifitas dan efisiensi anggaran, aspek lain yang dipandang berpengaruh terhadap belanja modal adalah SiLPA atau selisih lebih realisasi penerimaan dan pengeluaran anggaran selama satu periode anggaran. Ardhini dan Handayani (2011) dalam penelitiannya menyebutkan bahwa SiLPA berpengaruh positif dan signifikan terhadap realisasi belanja modal untuk pelayanan publik. Berdasarkan pemaparan di atas, maka dalam penelitian ini diturunkan hipotesis sebagai berikut:

$\mathrm{H}_{4}$ : SiLPA berpengaruh positif terhadap proporsi belanja modal yang diperuntukkan untuk pelayanan publik
Pemerintah pusat pada hakikatnya mengemban tiga fungsi utama yakni fungsi distribusi, stabilisasi dan alokasi. Fungsi distribusi dan fungsi stabilisasi pada umumnya lebih efektif dan tepat dilaksanakan oleh pemerintah pusat, sedangkan fungsi alokasi oleh Pemda yang lebih mengetahui kebutuhan, kondisi, dan situasi masyarakat setempat. Pembagian ketiga fungsi dimaksud sangat penting sebagai landasan dalam penentuan dasar-dasar perimbangan keuangan antara pemerintah pusat dan Pemda.

Kusnandar dan Siswantoro (2012) menyatakan bahwa Pemda mencukupi kebutuhannya dari APBD, sedangkan untuk pemerintahan adalah tanggung jawab pemerintah pusat dari APBN. Pemerintahan daerah dalam hal pendanaan dapat mengandalkan PAD (retribusi daerah, pajak daerah, hasil pengelolaan kekayaan daerah yang dipisahkan, dan PAD lainnya yang sah), dana perimbangan (DAU, DAK, dana transfer lainnya), pinjaman daerah dan lain-lain yang sah.

Di beberapa daerah, peran DAU sangat signifikan karena kebijakan belanja daerah lebih di dominasi oleh jumlah DAU dari pada PAD. Pada studi yang dilakukan oleh Milas dan Legrenzi (2001) menemukan bukti empiris bahwasanya dalam jangka panjang transfer berpengaruh terhadap belanja modal dan pengurangan jumlah transfer dapat menyebabkan penurunan dalam pengeluaran belanja modal. Penelitian Prakosa (2004) menunjukkan bahwa jumlah belanja modal dipengaruhi oleh dana alokasi umum yang diterima dari pemerintah pusat. Hasil penelitan Adi (2007) semakin memperkuat kecenderungan ini, dimana ia menemukan bahwa kemandirian daerah tidak menjadi lebih baik, bahkan yang terjadi adalah sebaliknya yaitu ketergantungan Pemda terhadap transfer pemerintah pusat (DAU) menjadi semakin tinggi. Hal ini memberikan adanya indikasi kuat bahwa perilaku belanja daerah khususnya belanja modal akan sangat dipengaruhi sumber penerimaan ini. Dari pemaparan ini dapat dikembangkan hipotesis penelitian sebagai berikut: 
$\mathrm{H}_{5}$ : DAU berpengaruh positif terhadap belanja modal yang diperuntukkan untuk pelayanan publik

Dana Alokasi Khusus (DAK) merupakan jenis dana perimbangan yang ditransfer ke daerah dengan tujuan khusus. Penelitian tentang pengaruh DAK terhadap belanja modal telah banyak dilakukan dan hasilnya adalah DAK berpengaruh pada belanja modal. Penelitian yang dilakukan oleh Sandhyakalaning (2013) menyebutkan bahwa DAK berpengaruh positif dan signifikan terhadap belanja modal. Penelitian ini menguatkan penelitian sebelumnya, yaitu penelitian yang dilakukan oleh Tuasikal (2008) yang menyatakan bahwa terdapat hubungan positif dan signifikan atara DAK dan belanja modal. Sejalan dengan itu, penelitian Nuarisa (2013) dan Wandira (2013) juga mengungkapkan hal yang sama, bahwa pengaruh DAK terhadap belanja modal adalah positif dan signifikan. Dari hasil penelitian di atas dapat disimpulkan bahwa semakin besar DAK yang diperoleh, maka alokasi belanja modal pun meningkat. Berdasarkan pemaparan di atas, maka dapat diturunkan hipotesis dalam penelitiian ini sebagai berikut:
$\mathrm{H}_{6}$ : DAK berpengaruh positif terhadap belanja modal yang diperuntukkan untuk pelayanan publik

\section{METODA PENELITIAN Populasi dan sampel}

Populasi pada penelitian ini adalah pemerintah kabupaten/kota di Indonesia. Analisis dilakukan terhadap data realisasi ABPD selama tiga periode yaitu 2010, 2011 dan 2012. Sampel dalam penelitian ini adalah kabupaten/kota yang telah menyusun laporan realisasi anggaran format SAP dari tahun 2010 sampai dengan tahun 2012 yang dipublikasikan oleh Dirjen Perimbangan Keuangan Pemerintah Daerah di www.djpk.depkeu.go.id. Pengambilan sampel dilakukan dengan metode purposive sampling yang menggunakan pertimbangan dan kriteria-kriteria berikut: (1) Daerah kabupaten/kota yang sudah ada dan tidak mengalami perubahan dari tahun 2010 sampai tahun 2012; (2) Tersedia data laporan realisasi APBD dari tahun 2010 sampai dengan tahun 2012; (3) Kabupaten/ kota yang dijadikan sampel memiliki data yang diperlukan secara lengkap.

Tabel 1: Prosedur Pemilihan Sampel

\begin{tabular}{|c|c|c|}
\hline No & Uraian & Total \\
\hline \multirow{3}{*}{1} & Jumlah total Pemerintah kabupaten/kota saat penelitian & \multirow{3}{*}{508} \\
\hline & Pemerintah Kabupaten : 410 & \\
\hline & Pemerintah Kota : 98 & \\
\hline 2 & $\begin{array}{l}\text { Jumlah Pemerintah kabupaten/kota yang tercatat pada hasil olahan Dirjen Perimbangan } \\
\text { Keuangan Pemerintah Daerah pada tahun } 2010 \text {. } \\
\text { Pemerintah Kabupaten : } 359 \\
\text { Pemerintah Kota : } 83\end{array}$ & 442 \\
\hline 3 & $\begin{array}{l}\text { Jumlah Pemerintah kabupaten/kota yang tercatat pada hasil olahan Dirjen Perimbangan } \\
\text { Keuangan Pemerintah Daerah pada tahun } 2011 \text {. } \\
\text { Pemerintah Kabupaten : } 346 \\
\text { Pemerintah Kota : } 73\end{array}$ & 419 \\
\hline 4 & $\begin{array}{l}\text { Jumlah Pemerintah kabupaten/kota yang tercatat pada hasil olahan Dirjen Perimbangan } \\
\text { Keuangan Pemerintah Daerah pada tahun } 2012 \text {. } \\
\text { Pemerintah Kabupaten : } 349 \\
\text { Pemerintah Kota : } 79\end{array}$ & 428 \\
\hline 5 & $\begin{array}{l}\text { Jumlah Pemerintah kabupaten/kota yang tercatat pada hasil olahan Dirjen Perimbangan } \\
\text { Keuangan Pemerintah Daerah yang memiliki data yang diperlukan secara lengkap } \\
\text { tiga tahun berturut-turut 2010-2012 }\end{array}$ & 142 \\
\hline & Total Sampel & 142 \\
\hline
\end{tabular}

Sumber: Data yang diolah (2014) 
Berdasarkan Tabel 1, jumlah pemerintah kabupaten/kota di Indonesia pada saat penelitian adalah 508 kabupaten dan kota. Berdasarkan situs resmi Dirjen Perimbangan Keuangan Pemerintah Daerah (www.djpk.depkeu.go.id), jumlah Laporan Realisasi Anggaran yang dipublikasikan pada tahun 2010 adalah sejumlah 442, tahun 2011 sejumlah 428 dan pada tahun 2012 adalah sebanyak 426. Berdasarkan kriteria yang telah ditetapkan diperoleh sampel sebanyak 142 pemerintah kabupaten/kota yang telah memenuhi kriteria sebagai obyek penelitian ini.

Tabel 2 menunjukkan klasifikasi sampel berdasarkan wilayah. Terlihat bahwa jumlah Pemda pada masing-masing wilayah telah mencukupi sampel data karena tidak terlihat kesenjangan jumlah yang signifikan. Hal ini dapat menggambarkan kondisi Pemda secara nasional. Sampel terbanyak adalah dari pulau Sumatera dengan jumlah 48 Pemda dan paling sedikit adalah dari pulau Kalimantan dengan jumlah 15 Pemda.

Tabel 2: Klasifikasi Sampel Berdasarkan Letak Geografis

\begin{tabular}{lc}
\hline \multicolumn{1}{c}{ Letak Geografis } & $\begin{array}{c}\text { Jumlah } \\
\text { Pemda }\end{array}$ \\
\hline Sumatera & 50 \\
Jawa dan Bali & 27 \\
Kalimantan & 12 \\
Sulawesi & 25 \\
Nusa Tenggara dan Papua & 28 \\
\hline \multicolumn{2}{c}{ Total } \\
\hline
\end{tabular}

Sumber : Data yang diolah (2014)

Tabel 3 menunjukkan klasifikasi proporsi belanja modal berdasarkan jenis wilayah. Terdapat 23 sampel dari pemerintah kota, dan 119 pemerintah kabupaten di Indonesia.

Tabel 3: Klasifikasi Sampel Berdasarkan Jenis Wilayah

\begin{tabular}{|c|c|}
\hline Jenis Wilayah & Jumlah Pemda \\
\hline Kota & 23 \\
\hline Kabupaten & 119 \\
\hline Total & 142 \\
\hline
\end{tabular}

Sumber : Data yang diolah (2014)

\section{Persamaan Regresi}

Alat analisis yang digunakan adalah analisis regresi berganda linier yang digunakan untuk melihat pengaruh pendapatan yaitu kemandirian daerah terhadap pengeluaran pemerintah yang berupa belanja modal. Data diolah dengan bantuan software SPSS seri 16.00. Pengujian hipotesis dilakukan dengan menggunakan model analisis regresi variabel independen terhadap variabel dependen (Sekaran, 1992). Persamaan regresi pada penelitian ini adalah:

$$
\begin{aligned}
\mathrm{Y} 1= & \alpha+b 1 \mathrm{X} 1+b 2 \mathrm{X} 2-b 3 \mathrm{X} 3+b 4 \mathrm{X} 4+b 5 \\
& X 5+b 6 \times 6+b 7 X 7+e 1
\end{aligned}
$$

Y1 = Proporsi Belanja Modal (PBM)

$\mathrm{X} 1=$ Kemandirian Daerah (KMND)

$\mathrm{X} 2$ = Efektivitas Keuangan Daerah (EFKT)

$\mathrm{X} 3=$ Efisiensi Keuangan Daerah (EFSN)

$\mathrm{X} 4=\mathrm{SiLPA}$

$\mathrm{X} 5=\mathrm{DAU}$

$\mathrm{X} 6=\mathrm{DAK}$

$\mathrm{b}=$ koefisien regresi untuk masing-masing variabel X

\section{Definisi Variabel Variabel Dependen}

Variabel dependen yang digunakan dalam penelitian ini adalah proporsi belanja modal (PBM). Belanja modal adalah belanja langsung yang digunakan untuk membiayai kegiatan investasi. Adapun rumus proporsi belanja modal adalah sebagai berikut:

$$
\text { Proporsi Belanja Modal }=\frac{\text { Belanja Modal }}{\text { Total Belanja }}
$$

\section{Variabel Independen}

\section{Kemandirian Daerah}

Rasio kemandirian daerah menunjukkan kemampuan Pemda dalam membiayai sendiri kegiatan pemerintahan, pembangunan, dan pelayanan kepada masyarakat yang telah mehaya $r$ pajak dan retribusi sebagai sumber pendapatan yang diperlukan daerah, yang 
dapat diformulasikan (Halim dalam Ardhini dan Handayani 2011) sebagai berikut:

Kemandirian Daerah $=\frac{\text { PAD }}{\text { Total Pendapatan Da }}$

Efektifitas Keuangan Daerah

Analisis efektifitas menggambarkan kemampuan Pemda dalam merealisasikan PAD yang direncanakan dibandingkan dengan target PAD yang ditetapkan (Ardhini dan Handayani, 2011). Rumusan rasio efektifitas yaitu:

\section{Efektivitas $=\frac{\text { Realisasi PADi }}{\text { Target Penerimaan PADi }}$}

\section{Efisiensi Keuangan Daerah}

Rasio efisiensi adalah rasio yang menggambarkan perbandingan antara output dan input atau realisasi pengeluaran dengan realisasi penerimaan daerah. Semakin kecil rasio ini, maka semakin efisien, begitu pula sebaliknya. Rasio efisiensi diukur dengan rumus:

Rasio Efisiensi $=\frac{\text { Realisasi pengeluaran }}{\text { Realisasi Pemasukan }}$

\section{$\underline{\text { SiLPA }}$}

Selisih antara surplus/defisit dengan pembiayaan neto inilah yang disebut sebagai Silpa, dimana Silpa ini menurut Peraturan Pemerintah Nomor 58 tahun 2005 merupakan Selisih lebih realisasi penerimaan dan pengeluaran anggaran selama satu periode anggaran (Ardhini dan Handayani 2011).

\section{Dana Alokasi Umum}

DAU adalah transfer yang bersifat umum dari pemerintah pusat ke Pemda untuk mengatasi eretimpangan horisontal dengan tujuan utama pemerataan kemampuan keuangan antar daerah (Ardhini dan Handayani 2011).

\section{Dana Alokasi Khusus}

Kebijakan DAK secara spesifik (www.djpk.depkeu.go.id) adalah untuk membantu daerah daerah dengan kemampuan keuangan di bawah rata-rata nasional, dalam rangka mendanai kegiatan penyediaan sarana dan prasarana fisik pelayanan dasar masyarakat yang telah merupakan urusan daerah.

\section{HASIL DAN PEMBAHASAN Analisis Statistik Deskriptif}

Proporsi belanja modal pada 142 Pemda yang diteliti tidaklah stabil. Tampak pada Tabel 4, terjadi penurunan jumlah Pemda dengan tingkat proporsi $0 \%$ - $10 \%$ dari $10,56 \%$ menjadi $3,52 \%$. Ini merupakan sesuatu yang positif yaitu meningkatnya political will untuk memperbesar proporsi belanja modal yang sangat kecil menjadi lebih tinggi. Akan tetapi, pada Pemda dengan proporsi yang sudah tinggi (proporsi diatas 30\%), terlihat adanya penurunan dari 16,20\% di tahun 2010 menjadi $10,52 \%$ di tahun 2012. Adapun proporsi belanja modal untuk kisaran $>20 \%-30 \%$ terlihat stabil sedangkan proporsi belanja modal di kisaran $>10 \%-20 \%$ menunjukkan peningkatan tajam dari $35,21 \%$ menjadi $47,89 \%$.

Tabel 4: Klasifikasi proporsi belanja modal Pemda berdasarkan tingkatper sentase

\begin{tabular}{|c|c|c|c|c|c|c|}
\hline \multirow{2}{*}{$\begin{array}{l}\text { Proporsi Belanja } \\
\text { Modal }\end{array}$} & \multicolumn{6}{|c|}{ Jumlah dan Persentase Pemda } \\
\hline & \multicolumn{2}{|c|}{2010} & \multicolumn{2}{|c|}{2011} & \multicolumn{2}{|c|}{2012} \\
\hline $0 \%-10 \%$ & 15 & $10,56 \%$ & 5 & $3,52 \%$ & 5 & $3,52 \%$ \\
\hline$>10 \%-20 \%$ & 50 & $35,21 \%$ & 66 & $46,48 \%$ & 68 & $47,89 \%$ \\
\hline$>20 \%-30 \%$ & 54 & $38,03 \%$ & 58 & $40,85 \%$ & 54 & $38,03 \%$ \\
\hline$>30 \%$ & 23 & $16,20 \%$ & 13 & $9,15 \%$ & 15 & $10,56 \%$ \\
\hline Total & 142 & $100,00 \%$ & 142 & $100,00 \%$ & 142 & $100,00 \%$ \\
\hline
\end{tabular}

Sumber: Data primer (2014) 
Berdasarkan Tabel 5 tentang klasifikasi proporsi belanja modal berdasarkan letak geografis, terlihat bahwa proporsi belanja modal terbesar untuk daerah Jawa dan Sulawesi berada pada kisaran $>10$ s/d 20\%, Adapun untuk daerah Sumatera, Kalimantan, Nusa Tenggara dan Papua, sebagian besar proporsi belanja modal Pemda berada pada kisaran $>20$ s/d 30\%. Proporsi belanja modal yang sangat rendah $(0-10 \%)$ masih ditemui di Sumatera dan Jawa. Adapun Pemda dengan proporsi belanja modal yang tinggi, banyak ditemui di Sumatera, Kalimantan dan Nusa Tenggara dan Papua.
Berdasarkan data klasifikasi wilayah pada Tabel 6, proporsi belanja modal pemerintahan kota terlihat berada pada kisaran $>10 \%$ s/d 30\%. Tidak terdapat pemerintahan kota dengan proporsi belanja modal yang sangat rendah maupun yang sangat tinggi.

Adapun untuk pemerintahan kabupaten, walaupun mayoritas proporsi juga paling banyak pada kisaran $>10 \%$ s/d $30 \%$ juga, masih terdapat $3 \%$ pada kisaran $0-10 \%$ dan $14 \%$ diatas diatas $30 \%$. Ini menunjukkan kondisi kabupaten di Indonesia sangatlah beragam.

Tabel 5: Klasifikasi Proporsi Belanja Modal Berdasarkan Letak Geografis untuk LRA Tahun 2012

\begin{tabular}{cccccc}
\hline \multirow{2}{*}{$\begin{array}{c}\text { Jumlah dan } \\
\text { persentase }\end{array}$} & Sumatera & $\begin{array}{c}\text { Jawa dan } \\
\text { Bali }\end{array}$ & Kalimantan & Sulawesi & $\begin{array}{c}\text { Nusa Tenggara } \\
\text { dan Papua }\end{array}$ \\
\cline { 2 - 6 } Jumlah Pemda & & 2 & & & \\
$0 \%-10 \%$ & 2 & 17 & 3 & 15 & 0 \\
$>10 \%-20 \%$ & 16 & 7 & 5 & 8 & 10 \\
$>20 \%-30 \%$ & 26 & 1 & 4 & 2 & 14 \\
$>30 \%$ & 6 & 27 & 12 & 25 & 4 \\
Jumlah & 50 & $7 \%$ & $0 \%$ & $0 \%$ & 28 \\
Persentase & & $4 \%$ & $25 \%$ & $\mathbf{6 0 \%}$ & $36 \%$ \\
$0 \%-10 \%$ & $32 \%$ & $\mathbf{6 3 \%}$ & $\mathbf{4 2 \%}$ & $32 \%$ & $\mathbf{5 0 \%}$ \\
$>10 \%-20 \%$ & $\mathbf{5 2 \%}$ & $4 \%$ & $33 \%$ & $8 \%$ & $14 \%$ \\
$>20 \%-30 \%$ & $12 \%$ & $100 \%$ & $100 \%$ & $100 \%$ & $100 \%$ \\
$>30 \%$ & $100 \%$ & & & & \\
Jumlah & & $100 \%$ &
\end{tabular}

Tabel 6: Klasifikasi Proporsi Belanja Modal

Berdasarkan Jenis Wilayah untuk LRA Tahun 2012

\begin{tabular}{ccc}
\hline \multirow{2}{*}{ Jumlah dan persentase } & \multicolumn{2}{c}{ Jenis Wilayah } \\
\cline { 2 - 3 } Jumlah Pemda & Pemerintahan kota & Pemerintahan Kabupaten \\
\hline$\%-10 \%$ & 0 & 4 \\
$>10 \%-20 \%$ & 12 & 51 \\
$>20 \%-30 \%$ & 11 & 47 \\
$>30 \%$ & 0 & 17 \\
Jumlah & 23 & 119 \\
Persentase & & \\
$0 \%-10 \%$ & $0 \%$ & $3 \%$ \\
$>10 \%-20 \%$ & $52 \%$ & $43 \%$ \\
$>20 \%-30 \%$ & $48 \%$ & $39 \%$ \\
$>30 \%$ & $0 \%$ & $14 \%$ \\
Jumlah & $100 \%$ & $100 \%$ \\
\hline
\end{tabular}




\section{Uji Asumsi Klasik}

Pengujian yang dilakukan untuk melihat dan menilai kualitas data dengan uji asumsi klasik. Sebelum dilakukan pengujian untuk menguji hipotesis dilakukan uji asumsi klasik menilai apakah terdapat bias dalam sampel yang diuji. Uji asumsi klasik dalam penelitian ini meliputi uji normalitas, uji multikolonieritas, uji autokorelasi dan uji heteroskedastisitas. Pengujian normalitas dilakukan dengan uji distribusi One-Sample Kolmogorov-Smirnov Tes dan diperoleh Asymp. Sig. (2-tailed) model 0.603 yang lebih besar dari nilai $\alpha$ $(0,05)$ sehingga dapat disimpulkan bahwa data berdistribusi normal. Uj multikolinearitas dilakukan dengan Collinearity Statistics untuk semua variable dan diperoleh nilai tolerance $>$ 0.10 dan nilai VIF $<10$. Hasil pengujian ini menunjukkan bahwa data yang diteliti bebas dari multikolinearitas.

Pengujian autokorelasi dilakukan dengan menggunakan Durbin Watson (DW) test dan diperoleh nilai DW sebesar 1,918. Jika dibandingkan dengan table DW dengan jumlah observasi $(n)=426$ dan jumlah variabel independent $6 \quad(\mathrm{k}=6)$, diperoleh $\mathrm{du}$ (upper) $=1,8306$. Oleh karena nilai $\mathrm{DW}=1,918<$ du $(1,8306)$ maka pada data yang diteliti dapat dikatakan tidak terjadi autokolerasi. Adapun pengujian heterokedastisitas dilakukan dengan menggunakan grafik scatterplots dan didapat titik-titik dalam grafik yang tidak membentuk pola tertentu atau menyebar secara acak baik di atas maupun di bawah angka 0 pada sumbu Y. Hal ini dapat disimpulkan bahwa tidak terjadi heteroskedastisitas pada model regresi yang diuji.

\section{Hasil Uji Hipotesis}

Koefisien determinasi (adjusted $R$ square) yang terlihat pada Tabel 7 mengindikasikan kemampuan persamaan regresi berganda untuk menunjukkan tingkat penjelasan model terhadap variabel dependen.

Berdasarkan tabel 7, besarnya koefisien determinasi (Adjusted $R$ Square) adalah 0,491 atau $49,1 \%$ yang berarti variabel independen dalam penelitian ini DAK, SiLPA, rasio efisiensi kemandirian daerah (EFSN), rasio kemandirian daerah (KMND), rasio efektifitas keuangan daerah (EFKT) dan DAU mampu menjelaskan variasi variabel dependen yaitu proporsi belanja modal (BM-PDT) sebesar $49,1 \%$, sedangkan sisanya sebesar $50,9 \%(100 \%-49,1 \%)$ dijelaskan oleh variabel bebas lainnya yang tidak diamati dalam penelitian ini.

Tabel 7:

Hasil Uji Koefisien Determinasi $\left(\mathrm{R}^{2}\right)$

Model Summary ${ }^{\mathrm{b}}$

\begin{tabular}{llrrrr}
\hline Model & R & R Square & Adjusted R Square & Std. Error of the Estimate & Durbin-Watson \\
\hline 1 & $.491^{\mathrm{a}}$ & .241 & .230 & .07054 & 1.918 \\
\hline
\end{tabular}

a. Predictors: (Constant), DAK, SiLPA, EFSN, KMND, EFKT, DAU

b. Dependent Variable: BM_PDT

Uji Signifikansi simultan (Uji Nilai F)

\begin{tabular}{llrrrrrr}
\multicolumn{7}{c}{ Tabel 8: Hasil Uji F } \\
ANOVA & & \\
\hline Model & & Sum of Squares & Df & Mean Square & F & Sig. \\
\hline 1 & Regression & .662 & 6 & .110 & 22.160 & $.000^{\mathrm{a}}$ \\
& Residual & 2.085 & 419 & .005 & & \\
& Total & 2.747 & 425 & & & \\
\hline
\end{tabular}

a. Predictors: (Constant), DAK, SiLPA, EFSN, KMND, EFKT, DAU

b. Dependent Variable: BM_PDT 
Tabel 9: Hasil Uji Nilai T

Coefficients $^{\mathrm{a}}$

\begin{tabular}{|c|c|c|c|c|c|c|}
\hline & \multirow[t]{2}{*}{ Model } & \multicolumn{2}{|c|}{ Unstandardized Coefficients } & \multirow{2}{*}{$\begin{array}{c}\begin{array}{c}\text { Standardized } \\
\text { Coefficients }\end{array} \\
\text { Beta } \\
\end{array}$} & \multirow[t]{2}{*}{$\mathrm{t}$} & \multirow[t]{2}{*}{ Sig. } \\
\hline & & $\mathrm{B}$ & Std. Error & & & \\
\hline \multirow[t]{7}{*}{1} & (Constant) & .212 & .054 & & 3.897 & .000 \\
\hline & KMND & -.166 & .078 & -.111 & -2.142 & .033 \\
\hline & EFKTF & .002 & .001 & .098 & 1.978 & .049 \\
\hline & EFSN & .057 & .055 & .048 & 1.032 & .302 \\
\hline & SiLPA & $-2.469 \mathrm{E}-9$ & .000 & -.047 & -1.028 & .305 \\
\hline & DAU & $-1.509 \mathrm{E}-7$ & .000 & -.442 & -5.016 & .000 \\
\hline & DAK & $5.480 \mathrm{E}-7$ & .000 & .179 & 2.129 & .034 \\
\hline
\end{tabular}

a. Dependent Variable: PBM

Uji nilai $F$ yang terlihat pada Tabel 8 pada dasarnya menunjukkan bahwa variabelvariabel independen dalam model penelitian mempunyai pengaruh secara bersama terhadap variabel dependen.

Berdasarkan Tabel 8 di atas, uji ANOVA atau F-test diperoleh nilai signifikansi $(0,000)<(0,05)$ yang berarti hasil pengujian secara simultan menunjukkan bahwa variabel DAK, SiLPA, rasio efisien keuangan daerah (EFSN), rasio kemandirian daerah (KMND), rasio efektifitas keuangan daerah (EFKT) dan DAU secara bersama-sama berpengaruh signifikan terhadap nilai proporsi belanja modal (BM-PDT).

\section{Uji Signifikansi Parameter Individual (Uji Nilai $t$ )}

Uji parsial (t test) digunakan untuk mengetahui pengaruh masing-masing variabel independen berpengaruh terhadap variabel dependen. Berdasarkan hasil pengujian dengan menggunakan alat analisis regresi linear berganda diperoleh hasil yang tampak pada Tabel 9 .

Dari hasil persamaan regresi pada table 9, diperoleh persamaan regresi sebagai berikut: $\mathrm{Q}=0,212-0,166 \mathrm{KMND}+0,002 \mathrm{EFKT}+$ 0,057 EFSN - 2.469 SiLPA - 1.509 $\mathrm{DAU}+5.480 \mathrm{DAK}+\mathrm{e}$

\section{Hasil pengujian hipotesis pertama}

Berdasarkan tabel 9, variabel rasio kemandirian daerah (KMND) memiliki nilai koefisien regresi sebesar -0,166 dengan signifikansi se- besar $0,033<0,05$. Ini menunjukkan variabel rasio kemandirian daerah (KMND) berpengaruh signifikan terhadap proporsi belanja modal (PBM) secara berlawanan arah, yaitu semakin tinggi rasio kemandirian, semakin kecil proporsi belanja modal. Dengan demikian hipotesis pertama bahwa kemandirian daerah berpengaruh positif terhadap belanja modal yang diperuntukkan bagi pelayanan publik tidak dapat diterima. Hasil dalam penelitian ini sejalan dengan penelitian Sandhyakalaning (2013), yang berpendapat bahwa kemandirian daerah berpengaruh negatif terhadap belanja modalPemda .

\section{Hasil pengujian hipotesis kedua}

Berdasarkan Tabel 9, variabel rasio efektifitas keuangan daerah (EFKT) memiliki nilai koefisien regresi sebesar 0,002 dengan signifikansi sebesar $0,049<0,05$. Ini menunjukkan variabel rasio efektifitas keuangan daerah (EFKT) terbukti berpengaruh positif signifikan terhadap proporsi belanja modal (PBM). Dengan demikian hipotesis kedua bahwa efektivitas keuangan daerah berpengaruh positif terhadap belanja modal yang diperuntukkan untuk pelayanan publik dapat diterima.

Rasio efektifitas keuangan daerah (EFKT) berpengaruh positif dan signifikan terhadap proporsi belanja modal (PBM). Hasil penelitian ini sejalan dengan penelitian Ardhini dan Handayani (2011) yang menyatakan bahwa rasio efektifitas keuangan daerah berpengaruh positif signifikan terhadap 
alokasi belanja modal untuk pelayanan publik. Ini diperkuat oleh penelitian Ardhini dan Handayani (2011) yang menyatakan bahwa rasio efektifitas keuangan daerah berpengaruh positif terhadap belanja modal untuk pelayanan public tahun berikutnya. Hal ini menunjukkan bahwa realisasi PAD dapat meningkatkan rasio efektifitas keuangan daerah, kemudian bisa dikatakan semakin efektif pemerintah kabupaten/kota maka akan mempengaruhi besar proporsi belanja modal untuk pelayanan publik.

\section{Hasil pengujian hipotesis ketiga}

Berdasarkan Tabel 9, variabel rasio efisiensi keuangan daerah (EFSN) memiliki nilai koefisien regresi sebesar 0,057 dengan signifikansi sebesar 0,302<0,05. Ini menunjukkan bahwa variabel efisiensi keuangan daerah (EFSN) terbukti tidak berpengaruh signifikan terhadap proporsi belanja modal (PBM). Dengan demikian hipotesis ketiga bahwa efisiensi keuangan daerah berpengaruh positif terhadap belanja modal yang diperuntukkan untuk pelayanan public tidak dapat diterima.

Rasio efisiensi keuangan daerah (EFSN) tidak berpengaruh terhadap proporsi belanja modal (PBM). Hasil penelitian ini bertentangan dengan hasil penelitian Vegasari (2011) yang berpendapat bahwa rasio efisiensi keuangan Pemda berpengaruh signifikan terhadap belanja modal tahun berikutnya. Perbedaan hasil penelitian ini dengan penelitian sebelumnya salah satunya adalah pada variabel dependennya yaitu pada penelitian sebelumnya menggunakan belanja modal nominal sedangkan pada penelitian ini menggunakan proporsi belanja modal. Sangat dimungkinkan terdapat peningkatan pada belanja modal nominal, namun tidak terjadi peningkatan pada proporsi belanja modal. Hal ini terjadi karena belanja modal nominal jika dibandingkan dengan total belanja akan terlihat proporsi belanja modal. Bisa jadi belanja modal nominal menunjukkan peningkatan, namun tidak terjadi peningkatan pada proporsi belanja modal. Hal ini dimungkinkan justru peningkatan proporsi terjadi pada belanja lain- nya seperti; belanja operasi atau belanja tidak terduga.

\section{Hasil pengujian hipotesis keempat}

Berdasarkan Tabel 9, variabel SiLPA memiliki nilai koefisien regresi sebesar $-2,469$ dengan signifikansi sebesar 0,305 > 0,05. Ini menunjukkan bahwa variabel SiLPA terbukti tidak berpengaruh signifikan terhadap proporsi belanja modal (PBM). Dengan demikian hipotesis keempat bahwa SiLPA berpengaruh positif terhadap proporsi belanja modal yang diperuntukkan untuk pelayanan publik, tidak dapat diterima.

SiLPA tidak berpengaruh terhadap proporsi belanja modal (PBM). Hasil penelitian ini bertentangan dengan penelitian Kusnandar dan Siswantoro (2012) dan Ardhini dan Handayani (2011) dalam penelitiannya menyebutkan bahwa SiLPA berpengaruh positif dan signifikan terhadap realisasi belanja modal. Hasil di atas menunjukkan bahwa meskipun peningkatan SiLPA dapat mempengaruhi belanja modal secara nominal, namun ternyata SiLPA tidak mempengaruhi pada alokasi proporsi belanja modal diasumsikan karena nilai SiLPA terlalu kecil sehingga tidak dapat memengaruhi nilai proporsi belanja modal. Selain itu, peningkatan belanja modal nominal belum tentu terjadi peningkatan pula pada proporsi belanja modal. Bisa jadi angka nominal belanja modal tinggi, namun jika dibandingkan dengan total belanja justru terlihat proporsi umtuk belanja modal masih rendah. Proporsi belanja modal ini yang kemudian dapat mengevaluasi kinerja pemerintah kabupaten/kota untuk terus meningkatkan pelayanan terhadap publik melalui belanja modal.

\section{Hasil Pengujian Hipotesis Kelima}

Berdasarkan Tabel 9, variabel DAU memiliki nilai koefisien regresi sebesar -1,509 dengan signifikansi sebesar $0,000<0,05$. Ini menunjukkan bahwa variabel DAU berpengaruh signifikan terhadap proporsi belanja modal (PBM) secara berlawanan arah yaitu semakin besar DAU semakin kecil proporsi belanja modal. Hasil ini menunjukkan hipotesis 
kelima bahwa DAU berpengaruh positif terhadap belanja modal yang diperuntukkan untuk pelayanan publik tidak dapat diterima.

DAU berpengaruh negatif namun signifikan terhadap proporsi belanja modal (PBM). Hasil penelitian ini sesuai dengan penelitian Prakosa (2004) menunjukkan bahwa jumlah belanja modal dipengaruhi oleh dana alokasi umum yang diterima dari pemerintah pusat. Sejalan dengan penelitian Adi (2007) mereka menemukan bahwa kemandirian daerah tidak menjadi lebih baik, bahkan yang terjadi adalah sebaliknya yaitu ketergantungan Pemda terhadap transfer pemerintah pusat menjadi semakin tinggi. Hasil diatas menggambarkan bahwa semakin besar DAU, maka semakin kecil proporsi belanja modal.

\section{Hasil pengujian hipotesis keenam}

Berdasarkan Tabel 9, variabel DAK memiliki nilai koefisien regresi sebesar 5,480 dengan signifikansi sebesar $0,034>0,05$. Ini menunjukkan bahwa variabel DAK berpengaruh positif dan signifikan terhadap proporsi belanja modal (PBM). Dengan demikian hipotesis kelima bahwa DAK berpengaruh positif terhadap belanja modal yang diperuntukkan untuk pelayanan publik dapat diterima.

DAK berpengaruh positif dan signifikan terhadap proporsi belanja modal (PBM). Hasil penelitian ini sejalan dengan penelitian yang dilakukan oleh Tuasikal (2008) menyatakan bahwa terdapat hubungan yang positif dan signifikan antara DAK dan belanja modal. Sejalan dengan penelitian Halim dan Abdullah (2003), Nuarisa (2013) dan Wandira (2013) juga mengungkapkan hal yang sama, bahwa pengaruh DAK terhadap belanja modal adalah positif dan signifikan. Hal ini menunjukkan bahwa peningkatan belanja modal nominal dan peningkatan proporsi belanja modal saling beriringan. Semakin tinggi angka DAK, maka semakin tinggi pula proporsi belanja modal yang diperuntukkan untuk publik.

\section{SIMPULAN}

Penelitian ini menunjukkan bahwa proporsi belanja modal pada pemerintahan kota terlihat relatif homogen pada kisaran $>10 \%$ s/d $30 \%$. Di pemerintahan kota, tidak terdapat proporsi belanja modal yang sangat rendah maupun yang sangat tinggi. Adapun pada pemerintahan kabupaten, proporsi belanja modal cukup bervariasi walaupun mayoritas proporsi juga paling banyak pada kisaran $>10 \%$ s/d $30 \%$ juga. Pada pemerintahan kabupaten masih terdapat 3\% daerah dengan proporsi belanja modal pada kisaran $0-10 \%$ dan $14 \%$ diatas diatas $30 \%$.

Berdasarkan pada pengujian yang telah dilakukan terhadap beberapa hipotesis dalam penelitian, hasilnya menunjukkan bahwa tidak semua variabel independen tersebut dapat mempengaruhi variabel dependen. Hasil penelitian dapat ditarik kesimpulan sebagai berikut ini: Pertama, Efektifitas keuangan daerah dan DAK berpengaruh positif terhadap proporsi belanja modal yang diperuntukkan untuk pelayanan publik. Kedua, Kemandirian daerah dan DAU berpengaruh negatif namun signifikan terhadap proporsi belanja modal yang diperuntukkan untuk pelayanan publik. Ketiga, rasio efisiensi keuangan daerah dan SiLPA tidak berpengaruh signifikan terhadap proporsi belanja modal yang diperuntukkan untuk pelayanan publik.

Terdapat beberapa keterbatasan dalam penelitian ini antara lain: Pertama, variabelvariabel yang digunakan sebatas pada informasi yang terdapat pada LRA. Kedua, periode penelitian yang digunakan relatif pendek hanya tiga tahun saja sehingga jumlah sampel yang digunakan juga terbatas dari segi rentang waktu. Ketiga tidak semua kabupaten kota menyerahkan LRA-nya sehingga hasil yang ada tidak bisa mengeneralisir Pemda yang LRA belum dipublikasikan ke publik. Keempat, penelitian ini hanya berdasarkan data kuantitatif dan belum memasukkan aspek kualtatif yang relevan menjadi faktor yan $g$ menentukan kebijakan alokasi belanja modal Pemda.

Penelitian selanjutnya dapat menambahkan variabel independen di luar LRA 
seperti dana otonomi khusus, luas wilayah, karakter kepala daerah serta strutur politik di daerah. Penelitian selanjutnya dapat menambahkan periode observasi yang lebih panjang, meneliti per regional, mengkaji secara mendalam aspek kualitatif sehingga dapat dinilai efektifiitas kebijakan fiskal Pemda melalui APBD. Pendekatan interview perlu dipertimbangkan untuk digunakan agar memahami secara lebih spesifik pertimbangan utama yang digunakan Pemda dalam menentukan alokasi belanja modal.

\section{DAFTAR REFERENSI}

Adi, P. H. 2007. Relevansi transfer Pemerintah Pusat dengan upaya pajak daerah studi pada Pemerintah Kabupaten dan Kota Se-Jawa. The 2nd National Conference UKWMS, Surabaya.

Anthony, R. N., dan V. Govindarajan. 2005. Management control systems. Jakarta: Salemba Empat.

Ardhini dan S. Handayani. 2011. Pengaruh rasio keuangan daerah terhadap belanja modal untuk pelayanan publik dalam prespektif terhadap teori keagenan: Studi pada Kabupaten dan Kota di Jawa Tengah. Diambil dari http://eprints.undip.ac.id/30929/1/JUR NAL.pdf (dikses 20 Oktober 2013)

Eisenhardt, K. M. 1989. Agency theory: An assessment and review. The Academy of Management Review 4 (1): 57-74.

Halim, A., dan S. Abdullah. 2003. Pengaruh dana alokasi umum (DAU) dan pendapatan asli daerah (PAD) terhadap belanja Pemerintah Daerah: Studi kasus Kabupaten/Kota di Jawa dan Bali. Simposium Nasional Akuntansi VI: 1140-1159.

Halim, A. 2002. Bunga rampai: Manajemen keuangan daerah (edisi pertama). Yogyakarta: UPP AMP YKPN.

Kusnandar dan D. Siswantoro. 2012. Pengaruh dana alokasi umum, pendapatan asli daerah, sisa lebih pembiayaan anggaran dan luas wilayah terhadap belanja modal. Simposium Nasional Akuntansi $X V$, Banjarmasin.

Milas, C., dan G. Legrenzi. 2011. Debt sustainability and financial crises: Evidence from the GIIPS. CESifo Working Paper No. 3594.

Nuarisa, S. A. 2013. Pengaruh PAD, DAU dan DAK terhadap Pengalokasian Anggaran Belanja Modal. Accounting Analysis Journal 2 (1).

Prakosa, K. B. 2004. Analisis pengaruh dana alokasi umum (DAU), dan pendapatan asli daerah (PAD) terhadap prediksi belanja daerah: Studi empirik di Wilayah Jawa Tengah dan DIY. Jurnal Akuntansi dan Auditing Indonesia 8 (2): 101-118.

Sandhyakalaning, J. 2013. Pengaruh kemandirian daerah, dana perimbangan, dan belanja pegawai terhadap belanja modal Pemerintah Daerah (pada Kabupaten/Kota di Indonesia periode 2008-2012), Simposium Nasional Akuntansi XVI.

Siregar, D. 2004. Manajemen aset. Jakarta: Gramedia Pustaka Utama.

Tuasikal, A. 2008. Pengaruh DAU, DAK, PAD dan PDRB terhadap belanja mdal Pemerintah Daerah Kabupaten/Kota di Indonesia. Jurnal Telaah \& Riset Akuntansi1 (2): 142-155.

Vegasari, E. K. 2011. Faktor-faktor yang menentukan pendapatan asli daerah dan belanja modal di Indonesia survei pada Pemerintahan Daerah di Indonesia bagian barat dan tengah.

Wandira, A. G. 2013. Pengaruh PAD, DAU, DAK dan DBH terhadap pengalokasian belanja modal. Accounting Analysis Journal 2 (1). 